\title{
ITERATIVE METHOD FOR IDENTIFICATION AND MAPPING OF COMPETENCES IN CURRICULUM CONSTRUCTION TO COMPUTER SCIENCE
}

\author{
Luiziana Rezende ${ }^{1}$, Lídia Micaela Segre ${ }^{2}$, Gilda Helena B. Campos ${ }^{3}$ \\ ${ }^{I}$ Doctorate Student at Rio de Janeiro Federal University (UFRJ - COPPE), Head of \\ Technology Education Institute at Gama Filho University, luiziana@ugf.br;
}

${ }^{2}$ Contributing Teacher to the Computer Science and Engineering Systems Doctorate Program (UFRI - COPPE), segre@cos.ufri.br;

${ }^{3}$ Distance Education Central Coordination -PUC-Rio, gilda@ccead.puc-rio.br

Abstract: This article introduces an approach per competence to curriculum construction in Computer Science and relevant implications, also demonstrating how important is to be familiar with theoretical - conceptual matrixes that the process involves. It proposes an Iterative Method for Identification and Mapping of Competences based on an analysis of pedagogic projects of Computer Science courses already implemented in Universities, which allows us to generate competence matrixes for Universities and Companies. Such matrixes, when crossed, should provide qualitative and quantitative contribution to Universities in constructing and developing pedagogic projects to Computer Science.

Keywords: Mapping of Competences, Curriculum Construction, Computer Science, Competence Matrixes 


\section{INTRODUCTION}

The first concern in this work regards the importance that the word "competences" is assuming in educational and corporate contexts, determining new ways of organizing university curricula, and also new ways of managing corporate knowledge. The word competence assumes different meanings, depending on the historical moment and context of use.

Thus, there appears a new dimension that gives a new meaning to the concept of competence, based on changes occurred in the world of work, of management of knowledge connected to development of complex cognitive capacities, i.e., competences related to theoretical dominium.

Several authors have focused the approach per competence in educational and organizational field, such as: Kuenzer (2002), Deluiz (2001), Zarifian (2001), Perrenoud (1999), Fleury (1999), Tanguy (1997), Naveira (1995), among others, and such way of approach is being presently proposed as a way of curriculum and pedagogic projects organization, in order to facilitate a graduate's profile specification. In this way, it is possible to design a relation between knowledge and competence that the graduate shall use in his/her professional field, thus joining work market requirements to a wider commitment with social and human development.

When defining competence as "a capacity to efficiently act in a given type of situation, supported by knowledge acquired, but without limitation to it", Perrenoud (1999, p.7) clearly explains the integration between competence and knowledge. According to him, "competences mobilize knowledge, placing knowledge in terms of relation and action, which can be complementary to each other".

That new requirement brings relevance to a study and research in that area, and it is scientists job to verify and establish existing relations between knowledge and competences, and also implications of such relations in the context of teaching institutions, which propose to develop them to form new professionals, and thus enabling an understanding of the work and education relationship for developing and mobilizing competences.

In the current scenario, mainly in technological area, competences vary as a result of changes in technology and quality standards, with a consequent need to diversify, improve, and value a professional formation, which is developed in Universities, in parallel to a theoretical and scientific formation.

Hence, the great challenge today for Universities is to provide a good and solid knowledge support to students, based on real experiences of learning, so that they could develop competences proposed in curriculum, and, thus, becoming people duly capable to face professional and social challenge. 


\section{REQUIREMENT TO CONSTRUCT CURRICULUM PROFESSIONAL LEVEL ACCORDING TO COMPUTER SCIENCE COMPETECEN}

In the beginning of the new millennium, computer science became an extremely dynamic and active area (ACM/IEEE 2001). Since its early times in the mid of last century, computer science is becoming essential to the contemporary world. Computers are a common part of culture and peoples lives. Moreover, computer science, specifically, keeps evolving in an amazing pace. New technologies are being continuously introduced, and those already existing are already obsolete within a few years. This fact has a profound effect on computer science courses, and affect both their content and pedagogic process.

The technological advance occurred last decade increased the importance of several curriculum items, among others: the World Wide Web and its applications; network technologies; especially those based on TCP/IP; multimedia; databank; inter-operations; object-oriented programming; dissemination of use of sophisticate application programming interfaces (API); human-computer interaction; security and cryptography (ACM/IEEE 2001).

Computer Science courses are generally included in the category of courses where computer skills are the final purpose, and where those who graduate shall remain inside a scientific state of the art regarding computer science, in such a way that they may keep developing their research activities, thus fostering a scientific development, or applying scientific knowledge, thus promoting a technological development and being capable of designing and building software, also being able to leverage and/or transform the work market with innovative ideas.

One can clearly see that a Computer Science Course gives emphasis to provide professional skills to the graduate, and also take care of its inclusion in the work market, in addition to prepare him/her to research and updating through post-graduate courses. The professional competence matter, however, is major, and is present throughout a curriculum construction in that area.

Regarding definition of professional competence, we have to consider a global definition of professional skills, i.e., responsibility field, and, after that, we must verify actions and competences that must be developed and mobilized, so that, under the best conditions possible, such professional skills may flourish. 
And what learning models, formations, temporalities, accompaniments, would be necessary so that such required competences could really develop themselves? What relation professional competences can keep with formal educational systems that could be acknowledged and assessed? This is a vital question that has been evaluated worldwide, in terms of education and organization.

There is great concern with acquisition and construction of competences in accordance with the working world. However, how can the formal educational system connect knowledge and competence?

Alain Savoyant (apud Zarifian, 2001, p. 176) proposes a distinction between two series of questions, in order to understand what the implications are: a) how to connect, when learning professional skills, educational activities and professional activities, when an alternation between them is only effective - and that should be evident - when similar things are learned in both situations, but through different and complementary ways?; b) how to insert alternation in an institutional scenario so that an individual who is under a learning process - a young person, for example - could really be followed up, without being isolated on his/her own?

We must say that a school situation articulates, as all practice does, skills learned based on experience, and not only on direct assimilation of concepts.

In these situations, reference, formally-built professional knowledge is important, and may be used as a source of properties related to a given problem situation, which can be simulated so that appropriate execution procedures could be deducted from them.

Those questions would be, then, a great difficulty when constructing a curriculum based on construction of competences to a Computer Science Course.

The next section focuses implications of adopting a competence model, initially characterizing theoretical-conceptual matrixes that may be reference to a curriculum organization per competence, and, finally, introduces method principles to a competence identification \& mapping as proposed herein.

\section{THEORETICAL-CONCEPTUAL MATRIXES FOR A CURRICULUM ORGANIZATION PER COMPETENCE}

There are several competence options, and to make an option for one of them is an important step towards a curriculum construction. When such 
decision is not related to the theoretical-conceptual matrix that is underlying to its definition, the expected results may not be fully accomplished, occurring several distortions between the expected graduate profile and the actual graduate profile.

According to Deluiz (2001, p. 23), "choices in terms of education are not neutral, and the option for a curriculum model based on competences shall express characteristics and interests of groups and social forces that elaborated them".

Several authors have contributed with indications for a curriculum organization per competence, but, if Universities, when constructing pedagogic projects, do not make connections to theoretical-conceptual matrixes, those competences would be deprived of meaning, and may have their practical application severely compromised.

Deluiz (2001, p. 19) says that: [...] the different conceptions found in a competence model indicate the existence of several theoretical-conceptual matrixes, which direct identification, definition, and construction of competences, and also a curriculum elaboration and organization. Such matrixes are linked to epistemological models that support them, and that may be identified as: conduction or behavior matrix; function matrix; construction matrix and critical-emancipative matrix; each one of them followed by an inherent analysis of the work process, in order to identify, define, and construct professional competences.

The following tables, constructed as from Deluiz studies (2001), summarize those four matrixes, for a comparative view on: a theoreticalconceptual base and fundaments used; objectives of a work process analysis, aiming to identify, define, and construct professional competences; the concept of competence used; the work process analysis object and method, and its relation with a curriculum.

Table 1- Conduction and Behavior Matrix

\begin{tabular}{|c|c|}
\hline Base & $\begin{array}{l}\text { Skinner's Psychology and Bloom's Pedagogy of } \\
\text { Objectives }\end{array}$ \\
\hline Objective & $\begin{array}{l}\text { Identify the tasks for each work post, and define a } \\
\text { formation curriculum; } \\
\text { social efficiency. }\end{array}$ \\
\hline $\begin{array}{l}\text { Competence } \\
\text { Concept }\end{array}$ & $\begin{array}{l}\text { Ability to reflect the capacity of a person, and to } \\
\text { describe what he/she can do or not, and what he/she } \\
\text { effectively does, notwithstanding situation or } \\
\text { circumstance. }\end{array}$ \\
\hline $\begin{array}{l}\text { Analysis Object } \\
\text { and Method }\end{array}$ & $\begin{array}{l}\text { Work post and definition of a formation curriculum; } \\
\text { Occupational analysis. }\end{array}$ \\
\hline $\begin{array}{l}\text { Relation with } \\
\text { Curriculum }\end{array}$ & $\begin{array}{l}\text { Behaviorist feature related to formulation of teaching } \\
\text { objectives in terms of noticeable conducts and }\end{array}$ \\
\hline
\end{tabular}




\begin{tabular}{ll}
\hline Base & Skinner's Psychology and Bloom's Pedagogy of \\
& Objectives \\
\hline practices; \\
Limitless taxonomies and fragmentation of objectives; \\
Limited curriculum, with narrow professional \\
formation.
\end{tabular}

Table 2. Functional Matrix

\begin{tabular}{ll}
\hline Base & $\begin{array}{l}\text { Functional thinking in Sociology; } \\
\text { Methodological-theoretical fundament and Theory of } \\
\text { Systems. }\end{array}$ \\
\hline Objective & $\begin{array}{l}\text { Originate work competence standards that describe } \\
\text { work results to be accomplished in a given work area; } \\
\text { corporate/institutional efficiency. }\end{array}$ \\
Competence & $\begin{array}{l}\text { Functions and tasks specified in competence } \\
\text { standards; } \\
\text { Subdivision according to units and competence } \\
\text { elements. }\end{array}$ \\
Analysis Object & $\begin{array}{l}\text { Identification of industry or company strategic } \\
\text { and Method }\end{array}$ \\
& $\begin{array}{l}\text { function and expected results of labor performance, in } \\
\text { functional analysis. }\end{array}$ \\
Relation with & $\begin{array}{l}\text { Curriculum constructed as from specified functions } \\
\text { Curriculum }\end{array}$ \\
& $\begin{array}{l}\text { and tasks according to competence standards; } \\
\text { learning restricted to activities and not to scientific- } \\
\text { technological fundaments; } \\
\text { limited curriculum, with narrow professional } \\
\text { formation. }\end{array}$ \\
\hline
\end{tabular}

Table 3. Constructivist Matrix

\begin{tabular}{|c|c|}
\hline Base & $\begin{array}{l}\text { Original from France, being Bertrand Schwartz one of } \\
\text { its main representatives. }\end{array}$ \\
\hline Objective & $\begin{array}{l}\text { Identify categories to construct an inventory of } \\
\text { competences, according to different situations, in } \\
\text { order to understand the competence/context relation, } \\
\text { as well as relevant construction and evolution } \\
\text { processes; } \\
\text { categories used in analysis: base culture; scientific, } \\
\text { technical, and organizational knowledge; behavioral } \\
\text { and relational knowledge; } \\
\text { constitute competences that are directed not only to } \\
\text { market, but also to personal potentialities and } \\
\text { objectives. }\end{array}$ \\
\hline Competence & relation between work activities and incorporated or \\
\hline
\end{tabular}




\begin{tabular}{|c|c|}
\hline Base & $\begin{array}{l}\text { Original from France, being Bertrand Schwartz one of } \\
\text { its main representatives. }\end{array}$ \\
\hline Concept & $\begin{array}{l}\text { mobilized knowledge. } \\
\text { constructive, procedural, collective, and contextual } \\
\text { dimension. }\end{array}$ \\
\hline $\begin{array}{l}\text { Analysis Object } \\
\text { and Method }\end{array}$ & $\begin{array}{l}\text { List of noticeable abilities and competences that a } \\
\text { group of individuals already had, and/or were } \\
\text { developed during the educational/action process; } \\
\text { privilege to the collective, both when analyzing the } \\
\text { work and how it is related to context, and individual } \\
\text { capacity, inserted in a collective capacity. }\end{array}$ \\
\hline $\begin{array}{l}\text { Relation with } \\
\text { Curriculum }\end{array}$ & $\begin{array}{l}\text { Enables to transfer investigated competences in a } \\
\text { work process through a pedagogic conception; } \\
\text { knowledge construction is an individual, subjective, } \\
\text { cognitive structures-developing process, according a } \\
\text { naturalist perspective of learning, without emphasis } \\
\text { on a social role context beyond the work limits during } \\
\text { subjective learning; } \\
\text { based on an enhanced concept of formation; but that } \\
\text { minimizes the social-political dimension. }\end{array}$ \\
\hline
\end{tabular}

Table 4. Critical-Emancipative Matrix

\begin{tabular}{ll}
\hline Base & Still under construction, based on dialectic thinking. \\
\hline Objective & Give a new significance to competence, in order to \\
& meet labor necessities; \\
& indicate main directives to: investigate work \\
processes; organize curriculum; and a wide & professional education proposition. \\
Competence & Various dimensions and various significances, \\
involving aspects ranging from the individual to \\
social-cultural, situational (contextual-organizational), \\
and procedural aspects.
\end{tabular}




\begin{tabular}{ll}
\hline Base & Still under construction, based on dialectic thinking. \\
\hline knowledge and a work experience; \\
acquiring formal knowledge together with acquiring \\
knowledge from work practice: know-how, values, \\
history, and experience. \\
based on a social dimension of knowledge \\
construction associated to professional dimension and \\
social-political dimension.
\end{tabular}

When relating the competence model to its theoretical-conceptual matrix, one can avoid a repetition of reductive educational models, which presently remain in the behavioral tradition of the competence model origin, or that favor only $\mathbf{n}$ insertion of graduates in a productive world, with knowledge enough to carry on professional activities only, according to market demands.

Moreover, it is possible to dissociate a curriculum according to competences from a non-critical perspective of education, mainly according to processes of social insertion and ability control to be developed, and, as a consequence, of teaching work control and social efficiency support.

Another danger that maybe brought by developing a curriculum in dissociation of a theoretical-conceptual matrix is to make graduates liable for a possible failure of insertion or endurance in the productive sector, and also for situation like unemployment, under-employment, independent work, and even exclusion due to their inaptitude to achieve/mobilize market-required competences.

Ferreti (FERRETI, 1999 apud ARAÚJO, 2002, p. 9) warns on “[...] a model that works on an assumption that everything in the professional field becomes an individual responsibility". Araújo (2002, p. 9), adds that "such focus may hide the fact that a definition, certification, and valorization of competences is a political and historical matter, as involves different and conflicting interests between capital and work".

Hence, it is important to note and avoid that conservative and narrowminded curriculum discourses appear with new critical and innovative appearance, inserted in context again, gaining legitimacy, and essentially serving to a social and productive efficiency point-of-view.

Considerations on these respects will give cause the curriculum components to be inserted in course structure, and they shall be of most importance to mobilize/develop competences.

Thus, empiric, qualitative studies of cases derived from other wider researches, or from selection of data collected in educational, teaching, and/or evaluation situations, must be performed inserted in a Brazilian context, to verify how the process of curriculum competence organization in Universities is carried out, identify respective implementation conditions, and success and failure situations, as well as potentials and limitations of models and theoretical-conceptual matrixes used. 
It is necessary, in those studies, the use of methods to identify and map competences, both in educational area and in productive sector. The first section focuses some known methods to identify and map competences, and introduces the principles of a method to be developed in this research.

\section{COMPETENCE IDENTIFICATION AND MAPPING METHODS}

Processes and methods for competence identification and mapping appeared in a corporate context, and are used by Human Resources to try to identify employees' competences, and map them according to area or level, for labor management.

With that purpose, instruments that showed employees' development needs, based on a comparison between levels of competences, required and demonstrated, and the way that people were integrated to the organization. The concept of competence is seen not just as "an inventory of knowledge, abilities, and acts of a given individual, but also the results, production, and deliveries that result of mobilizations under work situations" (OLIVEIRA NETO, 2002, p.6).

Under such focus different levels of delivery complexity to competences are defined, and they may be grouped according to centers, such as technological, managerial/administrative, and others.

A large portion of the literature reviewed on competence identification and mapping, is dedicated to the relation with methods on how to identify competences and abilities in people and employees, whether in a company or a contracted project, and also the relation with knowledge in specific areas, usually connected to use made by corporate Human Resources departments.

Regarding the educational area, no methods were found to identify and map competences required for a curriculum organization.

Therefore, a characteristic method was developed for this research, in order to identify and map competences in University's pedagogic projects and in corporations, and relevant principles are introduced during the next section.

\section{ITERATIVE METHOD FOR COMPETENCE IDENTIFICATION AND MAPPING}

Due to its innovative character, the competence identification and mapping process within an educational context must include teachers and students participation, which shall be continuous and result in an iterative 
process, i.e., a two-way process that goes under successive refinements until achieving a competence matrix that matches a pedagogical project of the studied institution.

The Iterative Method for Competence Identification and Mapping consists of three stages, based on activities described as follows:

1. Construction of a competence matrix according to University;

- Identification of competences in a University's pedagogic project;

- Mapping competences according to type; personal or subjective, social or communicative, natural or cognitive (technical or methodological);

- Designation of grades from 0 to 5 to each competence, according to grade of preponderancy in the development of a curriculum to a Computer Science Course;

- Association of competences to curriculum components mobilized during course development.

2. Construction of a competence matrix for companies, according to area of knowledge:

- Identification of corporate-required competences;

- Mapping competences according to type; personal or subjective, social or communicative, natural or cognitive (technical or methodological);

- Designation of grades from 0 to 5 to each competence, according to grade of preponderancy of the subject in the associated knowledge area;

- Association of competences to curriculum components mobilized during course development.

3. Crossing the University and Corporation competence matrix with the pedagogic project.

Therefore, we can obtain, at the end of the process, two competence matrixes, one for the University and one for the company, which, when crossed with the University pedagogic project, will direct the required analyses to the object of this research.

\section{CONCLUSION}

Several Universities have been constructing course projects based on a model of competences, nut without defining what model is that, and which is its basic theoretical-conceptual matrix, and that may bring distortions to the graduate profile we want to shape. Hence, it is necessary to know and think about the theoretical-conceptual matrixes and relevant implications when 
adopting them as base to develop a curriculum for Computer Science courses.

The introduction of a notion of competence in curriculum organization causes several changes when compared to the previous one, which focused objectives. An exclusive emphasis on new experiences and work ways in given situations without the support of relevant formal knowledge may lead to failure. However, formal knowledge only is not enough to assume efficacy.

It is worthy to note that the introduction of a competence notion in curriculum organization has also affected the professional formation of teachers, who shall play the role of active researchers, involved in the analyzed practices, as a way to understand their entire complexity and intervene to improve them.

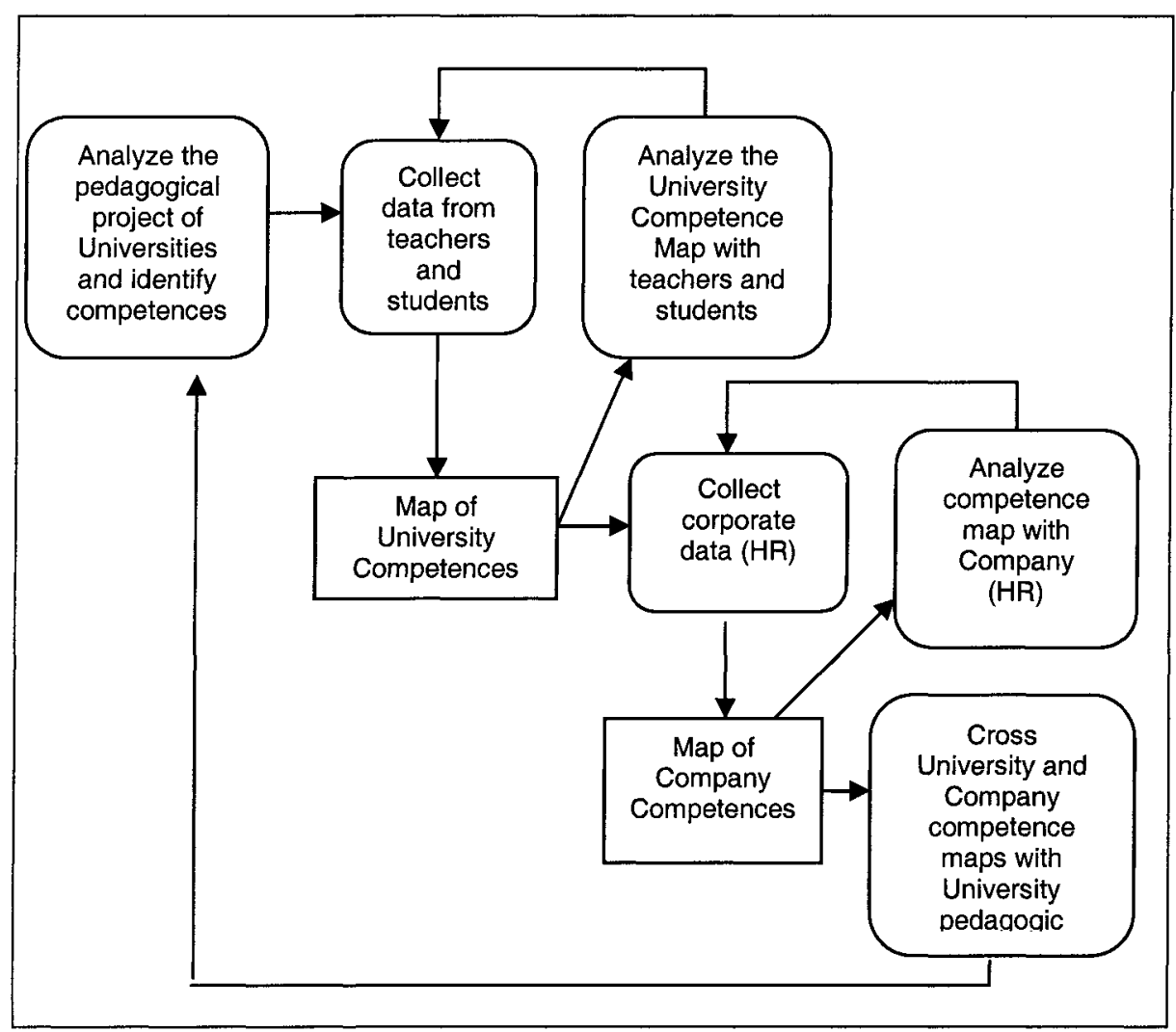

Figure 1. Iterative Process for competence identification and mapping 
There are several methods for mapping competences in Human Resources, which may not be fully applied to map competences in curricula for Computer Science courses.

The method we propose here intends to: analyze strategies, processes, methods, and resources that Universities presently use, and included in their pedagogic projects, which would enable the development of graduates of Computer Science Courses; map competences proposed in Computer Science Courses' pedagogic projects; map competences required of IT professional within an organizational context of some corporations; compare and cross competence maps generated in an educational context and an organizational context, in order to acquire information to support research conclusion; critical analysis of the relation between Computer Science graduates profile and competences developed/mobilized/required to work as a IT professional; contribute to Universities' construction process e and development of pedagogical projects to Computer Science Courses, through results obtained.

\section{REFERENCES}

ACM/IEEE. Proposta de currículo. 2001. Disponível em: <www.computer.org/education/cc2002/ironman/cc2001/index.html>

ACTIVE/COOPERATIVE LEARNING. Disponível em http://clte.asu.edu/active/.

BRASIL. Lei de Diretrizes e Bases da Educação, Lei no. 9394, de 20 de dezembro de 1996.

BRASIL. Certificação de competências profissionais: discussões. Brasília: OIT, TEM/FAT, 1999.

BRASIL. Metodologia para o estabelecimento de perfis profissionais. Projeto Estratégico Nacional. "Certificação Profissional Baseada em Competências. Brasília: 2000.

BRASIL. SEMTEC. Ministério da Educação e Secretaria de Educação Média e Tecnológica. Educação profissional: referências curriculares nacionais da educação profissional de nível superior. Brasília, 2001.

BRASIL/CNE. Resolução CEB. n.4, de 8 de dezembro de 1999. Institui as Diretrizes Curriculares Nacionais para a Formação de Professores de Educação Básica, em Nível Superior, Curso de Licenciatura e de Graduação Plena.

BRASIL/CNE. Parecer n. 009/2001. Institui as Diretrizes Curriculares Nacionais para a Educação Profissional de Nível Técnico.

BURNIER, S. Pedagogia das competências: conteúdos e métodos. Disponível em: $<$ www.ilo.org/public/spanish/region

CHAVES, E. O. C. Educação orientada para competências e currículo centrado em problemas. Disponível via URL http://chaves.com.br, 2004.

DELUIZ, N. O modelo das competências profissionais no mundo do trabalho e na educação: implicações para o currículo. Boletim Técnico do SENAC. Rio de Janeiro: v.27, n.3. set/dez., 2001.

Formação do trabalhador: produtividade e cidadania. Rio de Janeiro: Shape, 1995.

MAUÉS, O. C.; WONDJE, C.; GAUTHIER, C.Duas perspectivas diferentes em relação à abordagem por competências no ensino: os casos do Brasil e do Quebec. GT de Formação de Professores, n. 08. Disponível em: www.anped.org.br/25/olgaisesmauest08.rtf. 
MEC/SESu/CEEInf. Proposta de diretrizes curriculares de cursos da área de computação e informática. Brasília: Disponível via URL: www.mec.gov.br/sesu. 1999.

MERTENS, Leonard. La gestión por competencia laboral en la empresa y la formación profesional. Madrid: CUMBRE IBEROAMERICANA, 1998.

MITCHELL, L. H. R. G.; FUKS, H.; LUCENA, C. J. P. Extensão de modelos de competências para avaliação formativa e continuada e planejamento de recursos humanos. SBIE 2003.

REZENDE, L.; SEGRE, L. M.; CAMPOS, G. H. B. O projeto de fim de curso como componente curricular para o desenvolvimento e mobilização de competências nos cursos de graduação na área de computação e informática: um estudo introdutório. Anais do XXIII Congresso da Sociedade Brasileira de Computação (WEI). São Paulo, Campinas: agosto 2003.

ROSSATO, M.A. Gestão do conhecimento: a busca da humanização, transparência, socialização e valorização do intangível. Rio de Janeiro: Interciência, 2002.

SBC. Currículo de referência (CR). Disponível em <www.sbc.org.br $>$. Acesso em $15 / 08 / 2003$.

SETZER, V. W. Dado, informação, conhecimento e competência. Disponível em: <www.ime.usp.br/ vwsetzer/dado.info.html>. Acesso em: 29 fev 2004.

TIERNEY, M. The formation and fragmentation of computing as an occupation: a review of shifting "expertise". Programme on Information \& Communication Technologies. University of Edinburgh. Working paper n. $25,1991$.

WANG, $X$. Competency-based education. Disponível em www3.baylor.edu/ Xin_Wang/pdf/competency.pdf.. Acesso em 10 mar 2004.

ZARIFIAN, P. Objetivo competência: por uma nova lógica. Tradução Maria Helena C. V. Trylinski. São Paulo: Atlas, 2001. 